Stutthof - od miejsca odosobnienia do obozu koncentracyjnego. O historii zamkniętej $w$ albumie fotograficznym na marginesie lektury pracy Dwie godziny w listopadzie... Wizyta Heinricha Himmlera w obozie Stutthof 23 listopada 1941 roku: geneza, przebieg konsekwencje Marcina Owsińskiego ${ }^{1}$

\title{
Alicja Bartnicka
}

(1) http://orcid.org/0000-0001-7526-8325

Uniwersytet Mikołaja Kopernika w Toruniu

Dzieje Trzeciej Rzeszy czy historia II wojny światowej należą do tych zagadnień, które cieszą się niesłabnącym zainteresowaniem nie tylko zawodowych historyków, co z kolei znajduje wyraz w liczbie ukazujących się co roku nowych publikacji. I choć niektóre tematy wydają się na tyle dobrze opracowane, że trudno byłoby w ich zakresie powiedzieć coś jeszcze, badanie źródeł pod innym kątem czy dokonanie analizy nowego materiału w dalszym ciągu pozwala uzupełniać luki bądź przedstawiać opisywane wydarzenia z innej perspektywy. Dodatkowo warto wspomnieć także i o tym materiale historycznym, który w trakcie dociekań naukowych bywa przez badaczy nieco rzadziej wykorzystywany lub nawet całkowicie pomijany. Tymczasem dokumentacja ikonograficzna czy zachowane artefakty stanowią niezwykle cenne źródło wiedzy, mogące ukazywać historię nie tylko miejsc, lecz także wydarzeń czy zachodzących przemian.

Znakomitym przykładem wykorzystania tego typu materiału historycznego jest dwujęzyczna publikacja pt. Dwie godziny w listopadzie... Wizyta Heinricha Himmlera w obozie Stutthof 23 listopada 1941 roku: geneza, przebieg konsekwencje (Two Hours in November... Heinrich Himmler's visit to Stutthof camp on 23 November 1941: the background, the course and the consequences) przygotowana przez dr. Marcina Owsińskiego, która ukazała się w grudniu 2020 roku nakładem Muzeum Stutthof w Sztutowie. Podstawą analizy autora, umożliwiającą poprowadzenie

${ }^{1}$ M. Owsiński, Dwie godziny w listopadzie... Wizyta Heinricha Himmlera w obozie Stutthof 23 listopada 1941 roku: geneza, przebieg konsekwencje/Two Hours in November... Heinrich Himmler's visit to Stutthof camp on 23 November 1941: the background, the course and the consequences, Wydawca: Muzeum Stutthof w Sztutowie, Sztutowo 2020, ss. 111. Wszystkie cytaty pochodzą z tego wydania [numery cytowanych stron każdorazowo podano w tekście głównym, umieszczając je w nawiasie]. 
narracji wokół tytułowego wątku, stał się bogaty materiał ilustracyjny dokumentujący to wydarzenie. Materiał - dodajmy - który nie stanowił do tej pory przedmiotu rozważań historyków. Warto przyjrzeć się bliżej pracy doktora Marcina Owsińskiego i pochylić się nad prezentowanymi przez niego treściami, ponieważ tak istotna merytorycznie książka, choć niewielka w swym rozmiarze, nie powinna przejść bez echa.

Marcin Owsiński od ponad dwudziestu lat związany jest z Muzeum Stutthof, wypełniając obowiązki związane z funkcjami dyplomowanego kustosza, edukatora czy kierownika Działu Naukowego Muzeum. W jego dorobku znajduje się kilkadziesiąt publikacji naukowych i popularnonaukowych dotyczących historii najnowszej oraz dziejów Żuław, Stutthofu i Sztutowa. Do najważniejszych z nich bez wątpienia należą prace: Polscy więźniowie polityczni w obozie Stutthof 1939-19452, Pamiętamy, pamiętam... Pomorze Gdańskie i obóz Stutthof. Materiały edukacyjne ${ }^{3}$, Obóz-Muzeum. Trauma we wspótczesnym wystawiennictwie ${ }^{4}$, Stutthof: historia miejscowości i gminy od średniowiecza do maja 1945 rokus, Naznaczeni. Stutthof-Obozy - Sztutowo w latach 1945-1962. Dzieje gminy, gromady i miejsca pamięci ${ }^{6}$, Znaki (nie)pamięci. Teoria i praktyka upamiętniania w Polsce ${ }^{7}$, Tiegenhof / Nowy Dwór w 1945 roku. Koniec i początek miasta na Żuławach ${ }^{8}$, Żuławy w 1945 roku. Niedomknięte księgi, Stutthof 8/9 maja 1945. Historia i pamięć. Poza tym warto wspomnieć, że oprócz omawianej publikacji dotyczącej wizyty Himmlera w obozie Stutthof w ostatnim czasie ukazał się także przygotowany przez Marcina Owsińskiego i Tomasza Glinieckiego dwujęzyczny katalog wystawy Stutthof 8/9 maja 1945 r. Historia i pamięc ${ }^{10}$. Na podstawie przywołanego dorobku naukowego, popartego wieloletnią pracą w Muzeum Stutthof, widać wyraźnie, że Marcin Owsiński jest specjalistą w zakresie historii tego miejsca.

Biorąc pod uwagę dotychczasowy stan badań, tak w zakresie życia oraz działalności Heinricha Himmlera, jak i dziejów obozu Stutthof, trzeba przyznać, że na płaszczyźnie tych zagadnień niezwykle trudno znaleźć zupełnie nowy wątek, niepojawiający się w dotychczasowej literaturze. Bo czym innym jest, jak już wspomniano, badanie pewnych zjawisk pod różnym kątem lub przy odmiennym rozłożeniu

${ }^{2}$ Idem, Polscy więźniowie polityczni w obozie Stutthof 1939-1945, Toruń 2001.

${ }^{3}$ Pamiętamy, pamiętam... Pomorze Gdańskie i obóz Stutthof. Materialy edukacyjne, koncepcja i koordynacja projektu M. Owsiński; red. merytoryczny E. Górczak-Ulman; konsultant metodyczny A. Krajnowska, Warszawa-Sztutowo 2012.

${ }^{4}$ Obóz-Muzeum. Trauma we wspótczesnym wystawiennictwie, red. M. Fabiszak, M. Owsiński, Kraków 2013.

${ }^{5}$ M. Ow sińs ki, Stutthof: historia miejscowości i gminy od średniowiecza do maja 1945 roku, Sztutowo 2014 .

${ }^{6}$ Tegoż, Naznaczeni. Stutthof - Obozy - Sztutowo w latach 1945-1962. Dzieje gminy, gromady i miejsca pamięci, Sztutowo 2015.

${ }^{7}$ Znaki (nie)pamięci. Teoria i praktyka upamiętniania w Polsce, red. M. Fabiszak, A.W. Brzezińska, M. Owsiński, Kraków 2016.

${ }^{8}$ M. Owsiński, Tiegenhof/ Nowy Dwór w 1945 roku. Koniec i początek miasta na Żuławach, Sztutowo 2017.

${ }^{9}$ Żuławy w 1945 roku. Niedomknięte księgi, Stutthof 8/9 maja 1945. Historia i pamięć, red. T. Gliniecki, M. Owsiński, Sztutowo 2018.

${ }_{10}$ T. Gliniecki, M. Owsiński, Stutthof 8/9 maja 1945 r. Historia i pamięć: katalog wystawy/ Stutthof 8-th/9-th of May 1945. History and remembrance, Sztutowo 2020. 
akcentów, a czym innym wykazywanie istotnych elementów, które nie stanowiły do tej pory przedmiotu analizy. W obiegu czytelniczym funkcjonuje kilka biografii Himmlera, spośród których najbardziej znane są te autorstwa Williego Frischaue$\mathrm{ra}^{11}$, Heinricha Fraenkela i Rogera Manvella ${ }^{12}$, Petera Padfielda ${ }^{13}$ czy Petera Longericha ${ }^{14}$. W żadnej z tych prac nie pojawia się jednak wątek dotyczący wizyty Himmlera w obozie Stutthof i znaczenia wskazanego wydarzenia dla przyszłych losów tego miejsca. W publikacjach dotyczących samego obozu okoliczności związane z 23 listopada 1941 roku poruszane są niemal wyłącznie w kontekście późniejszych decyzji Himmlera i ich oddziaływania na funkcjonowanie Stutthofu ${ }^{15}$. W większości jednak prac naukowych wizyta Reichsführera SS, jeśli w ogóle jest wspominana ${ }^{16}$, to wyłącznie w kilku słowach, bez analizowania szczegółów z nią związanych ${ }^{17}$. Tymczasem Marcin Owsiński słusznie podkreślił, że to wydarzenie było jednym z najistotniejszych w historii tego miejsca, a z uwagi na jego późniejsze konsekwencje dla obozu winno doczekać się osobnego potraktowania, czego wyrazem stała się omawiana publikacja.

Praca Dwie godziny w listopadzie... została podzielona na cztery zasadnicze części, bardzo charakterystyczne dla prac historycznych. Autor już we wprowadzeniu zaznaczył, że podjęta problematyka, tj. okoliczności przyjazdu Himmlera do Stutthofu, szczegółowy przebieg programu wizyty i jej reperkusje nie były dotąd prezentowane w takiej formie, a wydarzenie to ,jest kluczem do zrozumienia podjętych wówczas decyzji” (s. 7). Przeprowadzona na kartach książki analiza była zatem konieczna dla nakreślenia mechanizmów działania Reichsführera SS, jak i specyfiki historii samego obozu Stutthof. „Kilka godzin pobytu H. Himmlera w Stutthofie zdecydowało bowiem o zasadniczej zmianie jego organizacji i zasięgu działania w kolejnych latach wojny oraz włączyło obóz w system państwowych obozów koncentracyjnych Trzeciej Rzeszy" - czytamy we wprowadzeniu Marcina Owsińskiego.

W rozdziale pierwszym otrzymaliśmy zarys genezy omawianych wydarzeń, począwszy od uwzględnienia ówczesnej sytuacji w Trzeciej Rzeszy, przez postać Himmlera i jego pozycję w niemieckim państwie w danym momencie, aż po

${ }^{11}$ W. Frischauer, Himmler: The Evil Genius of the Third Reich, London 1953.

${ }^{12}$ H. Fraenkel, R. Manve11, Himmler, London 1965.

13 P. Padfield, Himmler: Reichsführer SS, London 1990.

${ }^{14}$ P. Longerich, Heinrich Himmler: Eine Biographie, München 2008. Wydanie polskie: P. Longerich, Himmler. Buchalter śmierci, tłum. S. Szymański, J. Skow roński, Warszawa 2014.

${ }^{15}$ K. Ciechanowski, B. Chrzanowski, D. Drywa, E. Ferenc, A. Gąsiorowski, M. Gliński, J. Grabowska, E. Grot, M. Orski, D. Steyer, K. Stey er, Stutthof. Hitlerowski obóz koncentracyjny, Warszawa 1988, s. 228-229.

${ }^{16} \mathrm{~W}$ szeregu prac dotyczących obozu Stutthof nie pojawiają się nawet wzmianki na temat odbytej 23 XI 1941 r. wizyty Himmlera, która miała przecież decydujące znaczenie dla podporządkowania tego miejsca centrali obozów koncentracyjnych. Zob. M. Orsk i, Filie obozu koncentracyjnego Stutthof w latach 1939-1945, Gdański 2004; Obozy hitlerowskie na Pomorzu Zachodnim i Gdańskim w latach II wojny światowej, red. L. Janiszewski, Szczecin 1989; Stutthof. Ein Konzentrationslager vor den Toren Danzigs, Hrsg. H. Kuhn, Bremen 1995.

${ }^{17}$ K. Dunin-Wąsowicz, Obóz koncentracyjny Stutthof, Gdańsk 1970, s. 48, 67, 70; D. Drywa, Zagłada Żydów w obozie koncentracyjnym Stutthof (wrzesień 1939-maj 1945), Gdańsk 2001, 42-43. 
nominację na stanowisko Komisarza Rzeszy do Spraw Umacniania Niemczyzny (Reichskommissar für die Festigung deutschen Volkstums - RKF) i wynikające z niego uprawnienia (s. 12-13). Wszystkie te elementy zostały sprowadzone przez autora do istotnego z punktu widzenia podjętej problematyki wątku, a mianowicie prerogatyw Himmlera w zakresie germanizacji zajętych przez Trzecią Rzeszę terenów i konfliktów na tej płaszczyźnie z Albertem Forsterem - gauleiterem Okręgu Rzeszy Gdańsk-Prusy Zachodnie. Rozbieżność stanowisk w zakresie zniemczania miejscowej ludności (s. 14-15) stała się przyczyną wyjazdu inspekcyjnego Himmlera do Gdańska i na Pomorze. Wizytę w obozie Stutthof postanowiono zorganizować przy okazji, wykorzystując przede wszystkim fakt, że Reichsführer SS, jako zwierzchnik systemu państwowych obozów koncentracyjnych, jeszcze w Stutthofie nie był. Trudno zatem nie zgodzić się ze stwierdzeniem Marcina Owsińskiego, że okoliczności przyjazdu Himmlera świadczą o tym, iż Stutthof wcale nie był najważniejszym z punktów w jego programie (s. 15). Z drugiej jednak strony decyzje podjęte po tych wydarzeniach miały istotny wpływ na historię tego miejsca. Chcąc zatem wprowadzić czytelnika $\mathrm{w}$ to zagadnienie, autor pokrótce przedstawił okoliczności powstania obozu, podając dane niezbędne dla bliższego zrozumienia problemu. Co istotne - ta placówka była początkowo organizowana i finansowana przez struktury gdańskiej policji, wymykając się wpływom Himmlera i budząc tym samym jego niezadowolenie. W dalszej części tego rozdziału otrzymaliśmy sporo istotnych informacji dotyczących zagospodarowania przestrzennego tego miejsca, jego rozbudowy oraz stanu liczbowego więźniów w momencie wizyty Himmlera.

Część druga charakteryzowanej publikacji została poświęcona na omówienie przebiegu wizyty Himmlera na Pomorzu. Punktem wyjścia stały się ówczesne uwarunkowania polityczne i wspomniany już konflikt poglądów pomiędzy Himmlerem a Forsterem. Nie zabrakło także danych odnoszących się do towarzyszących Reichsführerowi SS ludzi - pełnionych przez nich funkcji czy zakresu obowiązków (s. 2729). W całości przytoczono także program delegacji najwyższych dowódców SS wyjeżdżających na Pomorze Gdańskie (s. 30-31). Analiza tego rozkładu spotkań potwierdziła wnioski wskazujące na to, iż ,główny nacisk w czasie kilku dni wyjazdu był położony na przekonanie A. Forstera, że metody zalecane przez urzędy SS należy stosować bez zastrzeżeń" (s. 34). Ponadto w odniesieniu do sporów poglądowych na linii Himmler-Forster Marcin Owsiński słusznie stwierdza, że „sukces obu stron był bardzo połowiczny - ani H. Himmler, ani A. Forster w efekcie poczynionych obserwacji i rozmów nie zmienili własnego zdania odnośnie prowadzonych przez siebie działań, nie spojrzeli także na siebie z większą sympatią..." (s. 34).

Kolejny, trzeci rozdział jest już gruntownym omówieniem dwugodzinnej wizyty Himmlera w Stutthofie, mającej miejsce 23 listopada 1941 roku. Znajdziemy w nim wszelkie istotne dla zrozumienia rangi tego wydarzenia informacje, począwszy od samego przyjęcia Reichsführera SS przez Maxa Pauly'ego - komendanta SS-Sonderlager Stutthof, po wnioski co do tego, w jaki sposób wizyta Himmlera wpłynęła na rozbudowę przestrzenną i zmiany administracyjne w obozie. Warto podkreślić, że autor usytuował całość narracji w koniecznym do zrozumienia wniosków końcowych kontekście historycznym, podając chociażby niezbędne informacje biograficzne na 
temat Pauly'ego, przedstawiając najważniejsze osoby zarządzające obozem czy odnosząc się do historii tego miejsca poprzez przywołanie danych dotyczących zajmowanego obszaru, liczby więźniów czy planów rozbudowy (s. 58). Zasadniczą, bardzo szczegółowo przedstawioną część tego rozdziału stanowi dokładna charakterystyka kolejnych etapów wizyty Himmlera. Autor w oparciu o bogaty, niepublikowany do tej pory materiał ikonograficzny dokonał analizy pozwalającej na podstawie najdrobniejszych nawet elementów pokazać nie tylko rangę tego wydarzenia, lecz także stan faktyczny obozu w tamtym momencie. Do wątku związanego z wykorzystaniem materiału zdjęciowego w analizie historycznej jeszcze wrócimy.

Ostatni, czwarty rozdział, zatytułowany Konsekwencje, zamyka ów przyczynowo-skutkowy ciąg narracji przyjętej przez autora. W treści skupiono się na podsumowaniu wizyty Himmlera w obozie Stutthof z 23 listopada 1941 roku i decyzjach, jakie krótko po tym wydarzeniu podjął względem tego miejsca. W wyniku kolejnych wizytacji oraz uzgodnień z dniem 8 stycznia 1942 roku Stutthof formalnie stał się państwowym obozem koncentracyjnym (s. 101-102). „W następnych miesiącach ostatecznie przekształcono organizację administracji obozu, wymieniono dużą część załogi z komendantem włącznie, zaczęto kierować do obozu więźniów z innych obozów koncentracyjnych, rozpoczęto wreszcie kolejny, zakrojony na olbrzymią skalę, etap przygotowania nowego terenu i rozbudowy infrastruktury" (s. 107). Działania te podjęto na podstawie listu z osobistymi sugestiami Himmlera, który jednoznacznie stwierdzał w nim, że „Stutthof musi zostać przejęty [...] jako obóz koncentracyjny z działalnością gospodarczą" (s. 101). Wizyta Reichsführera SS w wymiarze formalnym spowodowała zatem, że z niewielkiego, lokalnego miejsca odosobnienia Stutthof stał się samowystarczalnym kompleksem produkcyjnym, do którego na przestrzeni następnych lat przywieziono dziesiątki tysięcy nowych więźniów. Znaczna część z nich w tym miejscu zginęła (s. 107).

Podczas przeprowadzonej w pracy analizy Marcin Owsiński zwrócił szczególną uwagę na znaczenie pobytu Himmlera w Stutthofie dla załogi obozowej. Jak czytamy: „SS-mani ze sztabu Stutthofu mogli mieć niewątpliwie osobistą satysfakcję z udanego przebiegu wizyty ich szefa w obozie. Musiały to być wyjątkowo dobre wspomnienia, skoro poświęcono dużo czasu na uwiecznienie tego wydarzenia, aby do niego namacalnie i sentymentalnie wracać [podkreśl. - A.B.]" (s. 102). Mowa tutaj rzecz jasna o wykonanych wówczas zdjęciach, zebranych później w obszerny album fotograficzny, w całości poświęcony omawianej wizycie Himmlera. Album został przekazany do Państwowego Muzeum Stutthof (Archiwum Ikonograficzne) w 1964 roku przez mecenasa Bolesława Brulińskiego, który od jesieni 1945 roku pełnił funkcję wiceprokuratora Specjalnego Sądu Karnego w Gdańsku i był zaangażowany w śledztwo związane z pierwszym procesem stutthofskim. Wspomniana księga ze zdjęciami została odnaleziona we wrześniu 1945 roku w Lęborku w porzuconej dokumentacji poobozowej, którą wywieziono ze Stutthofu w tym samym roku. Jak można się domyślać, omawiane fotografie stanowiły materiał dowodowy w procesach przeciwko członkom załogi SS KL Stutthof, które miały miejsce w Gdańsku przed Sądem Okręgowym, a odbyły się w dniach od 8 października do 29 listopada 1947 roku. Obecnie album ze zdjęciami z listopadowej wizyty Himmlera stanowi najcenniejszy element 
zbiorów ikonograficznych Muzeum Stutthof. Co istotne - zdjęcia te są praktycznie jedynymi znanymi publicznie fotografiami pochodzącymi z okresu budowy i działalności obozu Stutthof (s. 105).

Ten bogaty materiał ilustracyjny stał się podłożem dla narracji Marcina Owsińskiego w publikacji Dwie godziny w listopadzie... Trzeba przyznać, że rzadko spotyka się dziś prace historyczne, gdzie bazę źródłową w przeważającej części stanowi ikonografia. O tym, że zdjęcia z okresu wojny i okupacji niosą z sobą obraz często bardzo tragicznych wydarzeń, nie trzeba jednak nikogo przekonywać. Wystarczy choćby wspomnieć o jednej z najbardziej rozpoznawanych dziś fotografii zatytułowanej Żydowska dzielnica mieszkaniowa w Warszawie już nie istnieje! Zdjęcie zostało wykonane w trakcie akcji likwidacyjnej warszawskiego getta, a jego głównym bohaterem jest kilkuletni chłopiec, stojący w grupie kobiet i mężczyzn. Dziecko ma uniesione do góry ręce $\mathrm{w}$ geście poddania się, a na jego twarzy widnieje grymas strachu i niepewności ${ }^{18}$. To zdjęcie, które stanowi obecnie pewnego rodzaju ikoniczny symbol zagłady, niesie z sobą nie tylko olbrzymi ładunek emocjonalny, ale jest także świadectwem barbarzyńskiej zbrodni ${ }^{19}$. O tym, jak wiele można wyczytać z powstałych w trakcie wojny fotografii, świadczy także zdjęcie wykonane podczas ostatniej masakry przeprowadzonej w kwietniu 1942 roku w miasteczku Winnica na zachodniej Ukrainie, kiedy to Einsatzkommando wymordowało wszystkich pozostałych przy życiu Żydów. W centralnej części obrazu widzimy żydowskiego mężczyznę przyklękającego nad wypełnionym ciałami rowem, za którym znajduje się celujący do niego z pistoletu członek niemieckiej grupy operacyjnej, otoczony przez innych mężczyzn w takich samych mundurach, obserwujących dokonywaną egzeku$\mathrm{cję}^{20}$. Reprodukcja tej fotografii jest jednym z głównych elementów wystawy stałej w berlińskim muzeum Topographie des Terrors, a szczegółowa analiza tego zdjęcia, zamieszczona w jego opisie na ekspozycji, pokazuje, jak wiele można wyczytać z pozy przyjętej przez oprawcę, kierunku, w którym patrzy ofiara, czy zachowania przyglądających się tej zbrodni członków Einsatzkommando ${ }^{21}$.

Zdjęcia wykorzystane przez Marcina Owsińskiego w publikacji Dwie godziny w listopadzie... z pewnością nie noszą tego rodzaju ciężaru gatunkowego, co wspomniane wyżej fotografie, jednak przeprowadzona przez autora analiza i interpretacja pokazują, jak przydatny może okazać się tego typu materiał w procesie rekonstrukcji

${ }_{18}$ Zdjęcie znajduje się w zasobie Archiwum Instytutu Pamięci Narodowej pod sygnaturą akt AIPN 2971/34. Reprodukcja fotografii została zamieszczona w publikacji IPN: Zbiór fotografii Głównej Komisji Badania Zbrodni Przeciwko Narodowi Polskiemu - Instytutu Pamięci Narodowej, red. T. S te mpowski, K.W. Ślusarski, Warszawa 2019 (wkładka ze zdjęciami „Wybrane karty z serii albumów”, brak paginacji wkładki).

${ }_{19}$ Zob. https://twojahistoria.p1/2018/01/16/to-najslynniejsze-zdjecie-z-getta-warszawskiego-co-powinienes-o-nim-wiedziec/ [dostęp: 25 II 2021 r.]; https://fotoblogia.pl/7291,zdjecie-z-likwidacji-getta-warszawskiego-ktore-stalo-sie-fotoikona-stolicy [dostęp: 25 II 2021 r.].

${ }^{20}$ Reprodukcja fotografii została zamieszczona w publikacji: R. Rhodes, Mistrzowie śmierci. Einsatzgruppen, tłum. M. Urbański, Warszawa 2015 (wkładka ze zdjęciami od s. 175, brak paginacji wkładki).

${ }^{21}$ Więcej informacji na stronie: https://www.topographie.de/topographie-des-terrors/ [dostęp: 25 II 2021 r.]. 
faktów historycznych. Wystarczy wspomnieć o kilku istotnych szczegółach uchwyconych na tych fotografiach, które pozwoliły badaczowi na wyciągnięcie istotnych wniosków końcowych. Jednym z takich elementów był samochód służbowy, jakim dysponował w tym czasie Himmler, tj. Horch $901 \mathrm{KfZ} 21$ Kommandeurscabriolet, uważany za reprezentacyjną wersję popularnego auta wojskowego. Rozpoznany rodzaj auta potwierdza wysoką już wówczas pozycję Reichsführera SS w narodowosocjalistycznych strukturach władzy, ponieważ w latach 1937-1942 wyprodukowano jedynie około 40 egzemplarzy tego wozu, a przydzielano go wyłącznie najwyższym generałom i dostojnikom partyjnym na podstawie decyzji samego Hitlera (s. 36). W pracy Owsińskiego nie brakuje także odniesień do dostrzeżonych na zdjęciach odznaczeń bądź naszywek (s. 44, 48, 53, 95), pozwalających na identyfikację rangi i przynależności organizacyjnej poszczególnych osób, czy też nawiązań do zabudowy zwiedzanego terenu (s. 50, 60), co z kolei w znacznym stopniu ułatwiło autorowi rekonstrukcję przemian w infrastrukturze tego miejsca.

Na osobne podkreślenie zasługuje dokonana przez autora weryfikacja wcześniejszych ustaleń. Materiał ikonograficzny, choć zdecydowanie dominuje, to jednak nie stanowi jedynej podstawy źródłowej wykorzystanej w omawianej publikacji i bardzo często był przez Marcina Owsińskiego konfrontowany czy uzupełniany na przykład o wspomnienia dotyczące tamtego okresu (s. 59-64). Zabieg ten pozwolił nie tylko wzbogacić narrację, lecz także podważyć nie dość jasne lub mylące relacje na temat wizyty Himmlera. Przykładem może być chociażby adnotacja zawarta przez Owsińskiego w jednym z przypisów: „W kolejnym akapicie autor wspomnień podaje też menu spotkania, jakie zapamiętał - wystawny trzydaniowy obiad. Jednak w konfrontacji tego ze zdjęciami i ich opisem wydaje się, że było to tylko śniadanie, a relacjonowane menu dotyczyć musiało innej oficjalnej delegacji, która w czasie kilku miesięcy pracy Mitury w kuchni SS odwiedzała obóz" (s. 82). Przedstawione tu wnioski zdają się w tym wypadku pokazywać niezaprzeczalną przewagę zachowanego materiału ilustracyjnego nad przekazem ustnym, często niestety zawodnym.

Przechodząc do omówienia innych aspektów recenzowanej publikacji, należy stwierdzić, że została ona bardzo starannie przygotowana pod kątem językowym, z drobnymi wyłącznie potknięciami stylistycznymi (s. 98, 107). Uwagę zwraca fakt, iż tekst przedłożono nie tylko w wersji polskiej, ale i angielskiej, co jest niewątpliwym walorem i z pewnością poszerzy krąg odbiorców. Do atutów należy również wydanie pracy na solidnym, grubym papierze, dzięki czemu otrzymaliśmy reprodukcje zdjęć naprawdę bardzo dobrej jakości. Zawodowi historycy bez wątpienia docenią również bogaty, jak na tych rozmiarów pracę, materiał źródłowy, uwzględniający nie tylko ów materiał ikonograficzny, lecz także źródła archiwalne, materiały wydane drukiem, prasę, relacje, dzienniki, pamiętniki czy wspomnienia. Całość zatem prezentuje się niezwykle solidnie, tak od strony merytorycznej, jak i pod względem jakości wydania.

Publikacja Dwie godziny w listopadzie... autorstwa Marcina Owsińskiego z Muzeum Stutthof w Sztutowie jest bez wątpienia pracą zasługującą na uwagę, tak osób zawodowo zajmujących się historią II wojny światowej, jak i laików zainteresowanych tym tematem wyłącznie hobbystycznie. Przedstawiona w niej wizyta Heinricha 
Himmlera w obozie Stutthof, która miała miejsce 23 listopada 1941 roku, została przez autora bardzo dokładnie przeanalizowana, a zaprezentowany materiał ikonograficzny pozwolił uwzględnić nawet najdrobniejsze elementy uchwycone $\mathrm{w}$ trakcie tego wydarzenia. Trzeba także pamiętać, że mówimy o książce, która mimo znacznego już dorobku naukowego w zakresie II wojny światowej, historii obozu Stutthof czy postaci Heinricha Himmlera uzupełnia pewne luki badawcze. Co istotne - publikacja Dwie godziny w listopadzie... jest dodatkowo znakomitym przykładem na to, jak ważne są badania mikrohistoryczne dla opisu zjawisk czy problemów o szerszym zasięgu. Warto zatem bliżej przyjrzeć się historii, która przed wieloma laty została uchwycona na zdjęciach i zamknięta w pewnym albumie fotograficznym. Albumie dodajmy - który dziś pozwala poznać przerażające dzieje miejsca, jakim na Pomorzu w latach II wojny światowej był obóz Stutthof. 